\title{
Vertical Segregation and
} Phylogenetic Characterization of Ammonia-Oxidizing Bacteria and Archaea in the Sediment of a Freshwater Aquaculture Pond

\author{
Shimin Lu ${ }^{1,2}$, Xingguo Liu ${ }^{1 *}$, Zhuojun $\mathrm{Ma}^{3 *}$, Qigen $\mathrm{Liu}^{2}$, Zongfan $\mathrm{Wu}^{4}$, Xianlei Zeng ${ }^{1,2}$, \\ $\mathrm{Xu} \mathrm{Shi}^{1}$ and Zhaojun $\mathrm{Gu}^{1}$
}

OPEN ACCESS

Edited by:

Mark Vincent Brown

University of New South Wales,

Australia

Reviewed by:

Lucas Stal,

Netherlands Institute of Sea Research

Netherlands

Wei Xie,

Tongji University, China

*Correspondence:

Xingguo Liu

liuxingguo@fmiri.ac.cn

Zhuojun Ma

mazj@cafs.ac.cn

Specialty section: This article was submitted to

Aquatic Microbiology,

a section of the journal

Frontiers in Microbiology

Received: 23 May 2015 Accepted: 21 December 2015

Published: 20 January 2016

Citation:

LU S, LiU X, Ma Z, LiU Q, Wu Z, Zeng $X$, Shi $X$ and Gu Z (2016) Vertical

Segregation and Phylogenetic Characterization of

Ammonia-Oxidizing Bacteria and

Archaea in the Sediment of a

Freshwater Aquaculture Pond.

Front. Microbiol. 6:1539.

doi: 10.3389/fmicb.2015.01539

\footnotetext{
${ }^{1}$ Fishery Machinery and Instrument Research Institute, Chinese Academy of Fishery Sciences, Shanghai, China, ${ }^{2}$ College of Fisheries and Life, Shanghai Ocean University, Shanghai, China, ${ }^{3}$ Chinese Academy of Fishery Sciences, Beijing, China,

${ }^{4}$ Tongren Municipal Agricultural Commission (Government, Public), Tongren, China
}

Pond aquaculture is the major freshwater aquaculture method in China. Ammoniaoxidizing communities inhabiting pond sediments play an important role in controlling culture water quality. However, the distribution and activities of ammonia-oxidizing microbial communities along sediment profiles are poorly understood in this specific environment. Vertical variations in the abundance, transcription, potential ammonia oxidizing rate, and community composition of ammonia-oxidizing bacteria (AOB) and ammonia-oxidizing archaea (AOA) in sediment samples (0-50 cm depth) collected from a freshwater aquaculture pond were investigated. The concentrations of the AOA amoA gene were higher than those of the $\mathrm{AOB}$ by an order of magnitude, which suggested that $\mathrm{AOA}$, as opposed to $\mathrm{AOB}$, were the numerically predominant ammonia-oxidizing organisms in the surface sediment. This could be attributed to the fact that AOA are more resistant to low levels of dissolved oxygen. However, the concentrations of the AOB amoA mRNA were higher than those of the AOA by 2.5- to 39.9-fold in surface sediments $(0-10 \mathrm{~cm}$ depth), which suggests that the oxidation of ammonia was mainly performed by $A O B$ in the surface sediments, and by $A O A$ in the deeper sediments, where only AOA could be detected. Clone libraries of $A O A$ and $A O B$ amoA sequences indicated that the diversity of $\mathrm{AOA}$ and $\mathrm{AOB}$ decreased with increasing depth. The $\mathrm{AOB}$ community consisted of two groups: the Nitrosospira and Nitrosomonas clusters, and Nitrosomonas were predominant in the freshwater pond sediment. All AOA amoA gene sequences in the $0-2 \mathrm{~cm}$ deep sediment were grouped into the Nitrososphaera cluster, while other AOA sequences in deeper sediments (10-15 and $20-25 \mathrm{~cm}$ depths) were grouped into the Nitrosopumilus cluster.

Keywords: freshwater aquaculture pond, ammonia-oxidizing archaea, ammonia-oxidizing bacteria, sediment, depth distribution 


\section{INTRODUCTION}

China is the world's largest producer, consumer, processor, and exporter of fish. China alone accounts for $>60 \%$ of the global aquaculture volume and roughly half of the global aquaculture value (Cao et al., 2015). Currently, there are 2,623,180 ha of freshwater aquaculture ponds, and freshwater pond culturing is the major culture method in China (National Bureau of Statistics of China 2014, http://www.stats.gov.cn/english/statisticaldata/ Quarterlydata/). To obtain more benefits from aquaculture, higher stocking densities are becoming prevalent. At the same time, large residual feed and feces are deposited into aquaculture sediments (Cao et al., 2015). A large amount of ammonia will be produced and released into the aquaculture water during the mineralization of organic matter. Ammonia not only significantly contributes to the eutrophication of aquaculture pond ecosystems, but is also one of the most toxic substances in intensive fish farming (Ackefors and Enell, 1994; Randall and Tsui, 2002). The high concentration of ammonia in aquaculture water has become a limitation for pond culturing in China.

Nitrification, the biological conversion of ammonia $\left(\mathrm{NH}_{3}\right)$ to nitrate via nitrite $\left(\mathrm{NO}_{2}^{-}\right)$, is a key process in nitrogen cycling in aquatic ecosystems (Merbt et al., 2012). Currently, the oxidation of $\mathrm{NH}_{3}$ to $\mathrm{NO}_{2}^{-}$- the first and rate-limiting step of nitrificationis considered to be conducted by ammonia-oxidizing bacteria $(\mathrm{AOB})$ and ammonia-oxidizing archaea (AOA; Koops and Pommerening-Röser, 2001). AOB fall into two phylogenetic lineages within the $\beta$ - and $\gamma$-Proteobacteria (Kowalchuk and Stephen, 2001) and mainly belong to the genera Nitrosomonas, Nitrosospira, and Nitrosococcus (Kowalchuk and Stephen, 2001; Wang et al., 2014a). Based on genomic level comparisons, AOA were classified into a newly proposed branching phylum of the Archaea, named the Thaumarchaeota (Pester et al., 2011), and a recent study showed that $\mathrm{AOA}$ could be grouped into five major clusters: the Nitrosopumilus cluster (also called group I.1a AOA), the Nitrosotalea cluster (also called group I.1a-associated AOA), the Nitrososphaera cluster (also called group I.1b AOA), the Nitrososphaera sister cluster, and the Nitrosocaldus cluster [also called thermophilic AOA (ThAOA); Pester et al., 2012]. AOB and $\mathrm{AOA}$ both contain a homologous ammonia monooxygenase (AMO) that is responsible for catalyzing the first step in ammonia oxidation. The amoA gene, encoding the alpha subunit of AMO, has been used widely as a functional gene marker for tracking ammonia oxidizers in environmental samples (Rotthauwe et al., 1997; Francis et al., 2005). Thus far, many studies of AOA and $\mathrm{AOB}$ have been conducted; however, most of them have focused on large ecosystems, such as soils (Leininger et al., 2006; Tourna et al., 2011), oceans (Wuchter et al., 2006; Horak et al., 2013), lakes (Ye et al., 2009; Auguet et al., 2011, 2012; Zhao et al., 2013), and rivers (Jin et al., 2011; Sun et al., 2013; Wang et al., 2014b). There is a lack of studies of AOA and AOB in aquaculture ponds. Pond environments are smaller in area and shallower in depth, have limited water circulation, and are subject to large depositions of feeding debris. Moreover, the hypolimnion dissolved oxygen concentration was very low, although the supersaturation of oxygen usually occurs in the top layer during the daylight period (Chang and Ouyang, 1988). The trophic status and sediment properties make freshwater aquaculture ponds a good model system for studying the vertical distribution of AOA and $\mathrm{AOB}$.

The oxidation of ammonium mainly occurs in the pond sediments, probably because of photoinhibition, and we previously found a low abundance of ammonia-oxidizing microorganisms in freshwater aquaculture water throughout the year (Lu et al., 2015). Hence, the aims of the present study were to investigate the activity and biodiversity in different sediment layers of a selected freshwater aquaculture pond in East China, and to quantitatively assess its $\mathrm{AOA}$ and $\mathrm{AOB}$. In order to better understand the vertical distribution of $\mathrm{AOA}$ and $\mathrm{AOB}$, we also partially characterized the physical and chemical factors $[\mathrm{pH}$, dissolved oxygen (DO), total organic carbon (TOC), ammonium $\left(\mathrm{NH}_{4}^{+}\right)$and $\left.\mathrm{NO}_{2}^{-}\right]$of the sediment.

\section{MATERIALS AND METHODS}

\section{Sediment Samples and Background}

Samples were collected from a freshwater aquaculture pond located at the Research Center for Pond Ecosystem Engineering, Chinese Academy of Fishery Sciences $\left[30^{\circ} 56^{\prime} \mathrm{N}, 121^{\circ} 09^{\prime}\right.$ E], Shanghai, China. The sampling pond had a surface area of $\sim 5000 \mathrm{~m}^{2}$ and an average depth of about $1.6 \mathrm{~m}$. Wuchang bream (Megalobrama amblycephala), grass carp (Ctenopharyngodon idella), silver carp (Hypophthalmichthys molitrix), and bighead carp (Hypophthalmichthys nobilis) were raised in the pond for commercial use from 2008 to 2011 and 2014 to 2015, and the production of fish was about $1200 \mathrm{~kg} \mathrm{~km}^{-2}$ per year. From 2012 to 2013, the submerged plant Chara fragilis Desv. was widely cultivated, and crab, whose production was about $150 \mathrm{~kg} \mathrm{~km}^{-2}$ per year, were raised in the sampled pond for commercial use. The sampled pond was dry during winter.

Three sediment cores ( $5 \mathrm{~cm}$ diameter and $50 \mathrm{~cm}$ depths) were collected from the aquaculture pond in October 2014 using a polyvinylchloride pipe. Then, the sediment cores were placed in sterile plastic bags, sealed, and transported to the laboratory on ice. Later, they were sectioned to $2 \mathrm{~cm}$ from 0 to $10 \mathrm{~cm}$ depths, and to $5 \mathrm{~cm}$ at $10-50 \mathrm{~cm}$ depths, and then we mixed the different cores from each sample for each depth. One portion was incubated to determine the ammonia oxidation activities immediately after arrival, another portion was used for an analysis of chemical components, and subsamples were stored at $-80^{\circ} \mathrm{C}$ for subsequent DNA and RNA extractions and molecular analysis.

\section{Chemical Analytical Procedures of Sediments}

Ammonium $\left(\mathrm{NH}_{4}^{+}-\mathrm{N}\right)$ and nitrite $\left(\mathrm{NO}_{2}^{-}-\mathrm{N}\right)$ were extracted from the sediments with $2 \mathrm{M} \mathrm{KCl}$ and measured photometrically using Nessler's reagent, and spectrophotometrically using $\mathrm{N}-(1-$ Naphthyl)-ethylenediamine dihydrochloride, respectively (Hou et al., 2003; Lu et al., 2015). The $\mathrm{pH}$ of sediment was determined after mixing it with water at a ratio (sediment/water) of 1:2.5, and sediment organic matter was determined using a total carbon analyzer (Vario TOC, Elementar, Germany; Zhu et al., 2011). In 
July 2015, sediment samples were collected in the same pond as previously described, and the DO concentration in fresh sediments was measured immediately on a fishing boat using an OXY Meter S/N 5015 with an microelectrode sensor (OX-50 $\mu \mathrm{m}$, Unisense, Aarhus, Denmark), as described by Gundersen et al. (1998).

\section{Measuring the Potential Ammonia Oxidation Rate}

Potential ammonia oxidation rates were measured using the chlorate inhibition method (Kurola et al., 2005). Briefly, $5.0 \mathrm{~g}$ of fresh sediment was added to $50 \mathrm{ml}$ centrifuge tubes containing $20 \mathrm{ml}$ of phosphate buffer solution $(\mathrm{NaCl}, 8.0$; $\mathrm{KCl}, 0.2 ; \mathrm{Na}_{2} \mathrm{HPO}_{4}, 0.2 ; \mathrm{NaH}_{2} \mathrm{PO}_{4}, 0.2 \mathrm{~g} \mathrm{~L}^{-1}$ ) containing $1 \mathrm{mM}\left(\mathrm{NH}_{4}\right)_{2} \mathrm{SO}_{4}$. Potassium chlorate was added to the tubes to a final concentration of $10 \mathrm{mM}$ to inhibit nitrite oxidation. The suspension was incubated with shaking (300 rpm) for $0.5 \mathrm{~h}$ at $25^{\circ} \mathrm{C}$ in the dark; then, the suspension was incubated without shaking for $24 \mathrm{~h}$ at $25^{\circ} \mathrm{C}$ in the dark; afterwards, nitrite was extracted with $5 \mathrm{ml}$ of $2 \mathrm{M} \mathrm{KCl}$ and determined spectrophotometrically at $540 \mathrm{~nm}$ using $\mathrm{N}$ (1-Naphthyl) ethylenediamine dihydrochloride. The potential ammonia oxidation rates were calculated based on the change in the nitrite concentrations.

\section{Nucleic Acid Extraction, Quantitative Polymerase Chain Reaction (qPCR), and Reverse Transcription}

Extraction of DNA from the sediment samples was conducted, and two controls were performed to estimate the possible inhibition of qPCR performance by the co-extracted polyphenolic compounds or humic acids in the sediment, as described by Lu et al. (2015). Total RNA was extracted from the sediment samples using the E.Z.N.A. ${ }^{\circledR}$ Soil RNA Mini Kit (Omega Bio-Tek, Norcross, GA, USA) according to the manufacturer's instructions. RNA was reverse transcribed into cDNA using the PrimeScript RT Master Mix (Perfect Real Time; TaKaRa Biotechnology Dalian Co., Ltd., Dalian, China). Absence of contamination from DNA and chemical reagents was verified by performing the same reactions without reverse transcriptase or template, respectively. The obtained cDNAs were stored at $-80^{\circ} \mathrm{C}$ for further analysis. $\mathrm{qPCR}$ was used to estimate the abundance of ammonia-oxidizing microorganisms' amoA mRNA and DNA, as well as total bacterial and Crenarchaeota $16 S$ rRNA genes. qPCR was performed using a SLAN real-time PCR detection system (Hongshi Medical Technology Co. Ltd., Shanghai, China). The primers and reaction conditions for qPCR are listed in Table 1. qPCRs were conducted in a total volume of $20 \mu \mathrm{L}$ containing $10 \mu \mathrm{L}$ of SYBR Premix Ex Taq II for the AOB amoA gene or SYBR Premix Ex Taq for the AOA amoA gene and total bacterial and Crenarchaeota $16 \mathrm{~S}$ rRNA genes (Takara), $1 \mu \mathrm{L}$ of DNA template, and $0.2 \mathrm{mg} \mathrm{mL}^{-1}$ bovine serum albumin (BSA). A negative control without DNA template was subjected to the same procedures to exclude or detect any possible contamination. After qPCR, the specificity of the amplification was verified by a melting curve analysis and agarose gel electrophoresis. All measurements were performed in triplicate.

Standard curves for qPCR were developed as described previously ( $\mathrm{Lu}$ et al., 2015). External standard curves ranging from $10^{1}$ to $10^{5}$ copies per microliter of the archaeal and bacterial amo $A$ genes or $10^{4}$ to $10^{8}$ copies of the bacterial and Crenarchaeota $16 \mathrm{~S}$ rRNA genes were generated during the process of qPCR. Standard curve coefficients of variation and efficiencies were as follows: AOA $\left(R^{2}=0.999\right.$, efficiency $=$ 94.4\%), AOB $\left(R^{2}=0.999\right.$, efficiency $\left.=90.9 \%\right)$, bacterial $16 \mathrm{~S}$ rRNA $\left(R^{2}=0.998\right.$, efficiency $\left.=90.0 \%\right)$ and crenarchaeota $16 \mathrm{~S}$ rRNA gene $\left(R^{2}=0.999\right.$, efficiency $\left.=82.7 \%\right)$. The results of the real-time PCR were expressed as the number of amoA or $16 \mathrm{~S}$ rRNA gene copies $g^{-1}$ of sediment (dry weight).

\section{Cloning, Sequencing, and Phylogenetic Analysis}

The purified PCR products were ligated and cloned using the pMD ${ }^{\mathrm{TM}} 18-\mathrm{T}$ Vector (Takara). In total, 105 and 76 clones of the AOA and $\mathrm{AOB}$ amoA gene PCR products, respectively, were successfully picked and sequenced. Operational taxonomic units (OTUs) were defined as sequence groups in which sequences differed by $\leq 2 \%$ for AOA and $\leq 3 \%$ for AOB. Neighbor-joining phylogenetic trees were constructed using MEGA 5.05 (Kumar et al., 2008).

\section{Statistical Analysis}

The estimated coverage of the constructed amoA gene libraries was calculated as $C=[1-(n / N)] \times 100 \%$, where $n$ is the number of unique OTUs and $N$ is the total number of all clones in a library. Indices of the $a m o A$ genotype diversity (Shannon-Wiener, H), richness estimations (Chao index), and rarefaction analysis were calculated using DOTUR (Schloss and Handelsman, 2005). Correlations between AOA abundance and environmental factors and One-way analysis of variance (ANOVA) were analyzed using SPSS 16.0 software.

\section{Nucleotide Sequence Accession Numbers}

The nucleotide sequences obtained in this study were deposited in the GenBank database under accession nos. KR081161KR081236 for AOB and KR081056-KR081160 for AOA.

\section{RESULTS}

\section{Abundances, Ammonia Oxidation Rates, and Expression of $A O A$ and $A O B$}

The vertical distribution profiles of TOC, $\mathrm{NH}_{4}^{+}-\mathrm{N}, \mathrm{NO}_{2}^{-}-\mathrm{N}$, and $\mathrm{pH}$ in every sediment core are shown in Figure 1. Briefly, the TOC, $\mathrm{NH}_{4}^{+}-\mathrm{N}$, and $\mathrm{NO}_{2}^{-}-\mathrm{N}$ concentrations were high in 0-6 cm sediments, and decreased rapidly from 6 to $10 \mathrm{~cm}$.

The concentrations of TOC, $\mathrm{NH}_{4}^{+}-\mathrm{N}$, and $\mathrm{NO}_{2}^{-}-\mathrm{N}$ ranged from $1.81 \pm 0.04$ to $17.60 \pm 0.85 \mathrm{~g} \mathrm{~kg}^{-1}, 3.88 \pm 0.45$ to 64.09 $\pm 11.01 \mathrm{mg} \mathrm{kg}^{-1}$, and $0.05 \pm 0.01$ to $0.47 \pm 0.16 \mathrm{mg} \mathrm{kg}^{-1}$, respectively. The $\mathrm{pH}$ ranged from 7.42 to 8.33 , and the lowest and the highest value occurred at the $0-2$ and $45-50 \mathrm{~cm}$, respectively. 
TABLE 1 | Primers used for PCR amplification for library construction and real-time PCR quantification.

\begin{tabular}{|c|c|c|c|c|c|}
\hline Target gene & Primer & Sequence $\left(5^{\prime}-3^{\prime}\right)$ & Concentration (nM) & Condition & References \\
\hline \multirow[t]{2}{*}{ AOA amoA } & Arch-amoAF & STAATGGTCTGGCTTAGACG & 200 & $95^{\circ} \mathrm{C}$ for $30 \mathrm{~s} ; 35$ cycles of $95^{\circ} \mathrm{C}$ for $5 \mathrm{~s}, 53^{\circ} \mathrm{C}$ & Francis et al., 2005 \\
\hline & Arch-amoAR & GCGGCCATCCATCTGTATGT & 200 & $\begin{array}{l}\text { for } 1 \mathrm{~min}, 72^{\circ} \mathrm{C} \text { for } 70 \mathrm{~s} \text {, and } 80^{\circ} \mathrm{C} \text { for } 20 \mathrm{~s} \\
\text { (read plant); }\end{array}$ & \\
\hline \multirow[t]{2}{*}{$\beta-A O B$ amoA } & amoA-1F & GGGGTTCTACTGGTGGT & 200 & $95^{\circ} \mathrm{C}$ for $30 \mathrm{~s} ; 40$ cycles of $95^{\circ} \mathrm{C}$ for $5 \mathrm{~s}, 54^{\circ} \mathrm{C}$ & Rotthauwe et al., 1997 \\
\hline & $a m o A-2 R$ & CCCCTCKGSAAAGCCTTCTTC & 200 & $\begin{array}{l}\text { for } 40 \mathrm{~s}, 72^{\circ} \mathrm{C} \text { for } 70 \mathrm{~s} \text {, and } 80 \text { for } 20 \mathrm{~s} \text { (read } \\
\text { plant); }\end{array}$ & \\
\hline Bacteria & $1055 f$ & ATGGCTGTCGTCAGCT & 400 & 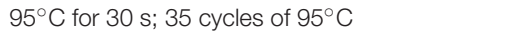 & Amann et al., 1995 \\
\hline $16 \mathrm{~S} r \mathrm{RNA}$ & $1392 r$ & ACGGGCGGTGTGTAC & 400 & for $5 \mathrm{~s}, 54^{\circ} \mathrm{C}$ for $45 \mathrm{~s}, 72^{\circ} \mathrm{C}$ for $45 \mathrm{~s}$ (read plant); & Wilson et al., 1990 \\
\hline Crenarchaeota & $771 \mathrm{~F}$ & ACGGTGAGGGATGAAAGCT & 400 & $95^{\circ} \mathrm{C}$ for $30 \mathrm{~s} ; 40$ cycles of $95^{\circ} \mathrm{C}$ for $5 \mathrm{~s}, 54^{\circ} \mathrm{C}$ & Torsten et al., 2003 \\
\hline $16 \mathrm{~S}$ rRNA & 957R & CGGCGTTGACTCCAATTG & 400 & $\begin{array}{l}\text { for } 45 \mathrm{~s}, 72^{\circ} \mathrm{C} \text { for } 40 \mathrm{~s} \text {, and } 80^{\circ} \mathrm{C} \text { for } 20 \mathrm{~s} \text { (read } \\
\text { plant); }\end{array}$ & \\
\hline
\end{tabular}

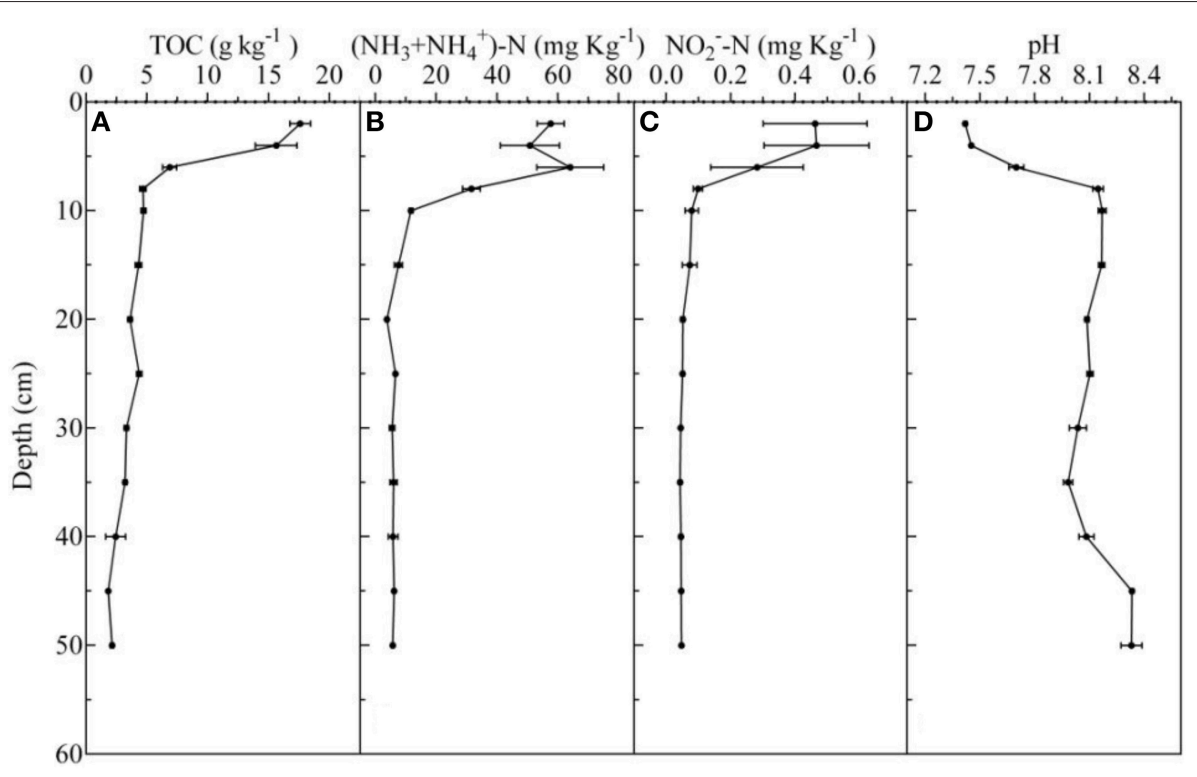

FIGURE 1 | Vertical distribution of total organic matter (A), ammonia nitrogen (B), nitrite nitrogen (C), pH (D), which was detected in October 2014.

The depth of the DO detection limit was $500 \mu \mathrm{m}$, and the DO concentrations ranged from 0 to $48.01 \mu \mathrm{mol} \mathrm{L}^{-1}$ (Figure 2).

To detect the presence of $\mathrm{AOA}, \mathrm{AOB}$, as well as the Crenarchaeota and total bacterial, the amoA and 16S rRNA genes from sediment core samples were amplified. The results showed that the depth limits for detecting the $\mathrm{AOA}$ and $\mathrm{AOB}$ amoA genes were 25 and $6 \mathrm{~cm}$, respectively, and that the concentrations of the AOA amoA gene (ranging from $6.82 \pm 2.28 \times 10^{4}$ to $7.79 \pm 3.88 \times 10^{5}$ ) were higher than those of the $\mathrm{AOB}$ $\left(1.88 \pm 0.39 \times 10^{3}\right.$ to $\left.3.60 \pm 0.91 \times 10^{4}\right)$ by an order of magnitude, which suggested that the AOA, as opposed to the $\mathrm{AOB}$, were the numerically predominant ammonia-oxidizing organisms in the surface sediment (Figure 3). Additionally, a positive PCR product was obtained for the Crenarchaeota and total bacteria in every sample, and the $16 \mathrm{~S}$ rRNA concentrations ranged from $4.94 \pm 2.12 \times 10^{6}$ to $6.18 \pm 1.33 \times 10^{8}$, and 6.10 $\pm 0.36 \times 10^{7}$ to $1.62 \pm 0.04 \times 10^{11}$ copies $\mathrm{g}^{-1}$, respectively (Figure 3). Linear relationships between different environmental factors and the amoA gene abundance of the $\mathrm{AOA}$ and $\mathrm{AOB}$ were characterized using Pearson's correlation coefficient. It was found that the abundance of $\mathrm{AOA}$ and $\mathrm{AOB}$ positively correlated with the TOC in the sediments $\left(R^{2}=0.838, P<\right.$ $0.01 ; R^{2}=0.852, P<0.01$ ), while the $\mathrm{AOA}$ and $\mathrm{AOB}$ abundances were negatively correlated with $\mathrm{pH}\left(R^{2}=-0.755\right.$, $P<0.01 ; R^{2}=-0.787, P<0.05$, respectively). No significant correlations were detected between the $\mathrm{AOA}$ and $\mathrm{AOB}$ abundances and the concentrations of $\mathrm{NH}_{4}^{+}-\mathrm{N}$ and $\mathrm{NO}_{2}^{-}-\mathrm{N}$ in sediments.

To obtain more detailed information about the AOA and $\mathrm{AOB}$ in the freshwater aquaculture pond sediments, the potential ammonia oxidation rate was obtained from every sample, and it ranged from $0.0014 \pm 0.0001$ to $0.0386 \pm 0.0028 \mathrm{mg} \mathrm{kg}^{-1} \mathrm{~h}^{-1}$. The potential ammonia oxidation rates in $0-6 \mathrm{~cm}$ deep sediments were significantly higher than those in other sediment layers $(P<0.01$; One-way ANOVA; Figure 3A). The expression of the $\mathrm{AOA}$ and $\mathrm{AOB}$ amoA genes was calculated using the abundance 
of the PCR products that were amplified from cDNAs. Despite the fact that the depth of the AOB detection limit was $6 \mathrm{~cm}, \mathrm{AOB}$ amo $A$ gene expression could be detected at $8-10 \mathrm{~cm}$ in sediment cores, and it was higher than that of AOA in $0-10 \mathrm{~cm}$ depths by 2.5-39.9-fold (Figure 4).

\section{Diversity of $A O A$ and $A O B$}

To investigate the diversity and community composition of ammonia-oxidizing populations, sediment layers with depths of

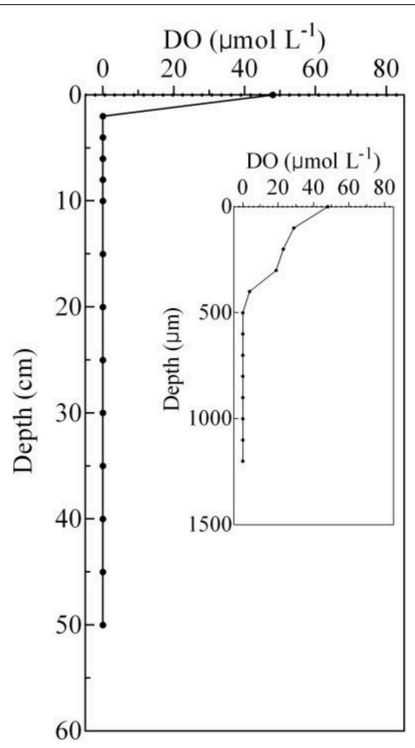

FIGURE 2 | Vertical distribution of DO in the sediment cores, which was detected in July 2015.
$0-2$ and $4-6 \mathrm{~cm}$, as well as $0-2,10-15 \mathrm{~cm}$, and $20-25 \mathrm{~cm}$, were selected for the construction of clone libraries of bacterial and archaeal amoA genes, respectively. Five clone libraries of the $a m o A$ gene were constructed to explore the diversity of $\mathrm{AOB}$ and AOA. The estimated coverage $(\mathrm{C})$ of the five clone libraries ranged from 91 to $100 \%$, which, together with the rarefaction analysis (Figure 5), indicated that the bacterial and archaeal amo $A$ genotypes in the sediments could be well-represented by these clone libraries. As shown in Figure 5A, the OTU numbers, Chao estimate, and Shannon index of AOB in the 4$6 \mathrm{~cm}$ deep sediment were all less than those of $\mathrm{AOB}$ at a 0 $2 \mathrm{~cm}$ depth, which indicated that the diversity of AOB decreased with increasing sediment depth. A phylogenetic analysis of bacterial amoA sequences suggested that the AOB community in aquaculture pond sediments consisted of two groups: the Nitrosospira and Nitrosomonas clusters (Figure 6A). The sequences related to Nitrosomonas spp. were predominant over those of Nitrosospira in $\mathrm{AOB}$ communities in the freshwater pond sediment.

An obvious variation in the AOA community and structure with sediment depth was also observed. As shown in Figure 5B, the diversity of AOA decreased with increasing sediment depth. All the AOA amoA gene sequences in $0-2 \mathrm{~cm}$ deep sediments were grouped into the Nitrososphaera cluster, while all the AOA sequences in $10-15 \mathrm{~cm}$ deep sediments, as well as a portion of the AOA sequences in the 20-25 deep sediments were grouped into a branch that belongs to the Nitrosopumilus cluster; the other AOA sequences in the $20-25 \mathrm{~cm}$ deep sediments were grouped into another branch of the Nitrosopumilus cluster. No sequences belonging to the ThAOA and Nitrosotalea clusters were detected (Figure 6B).

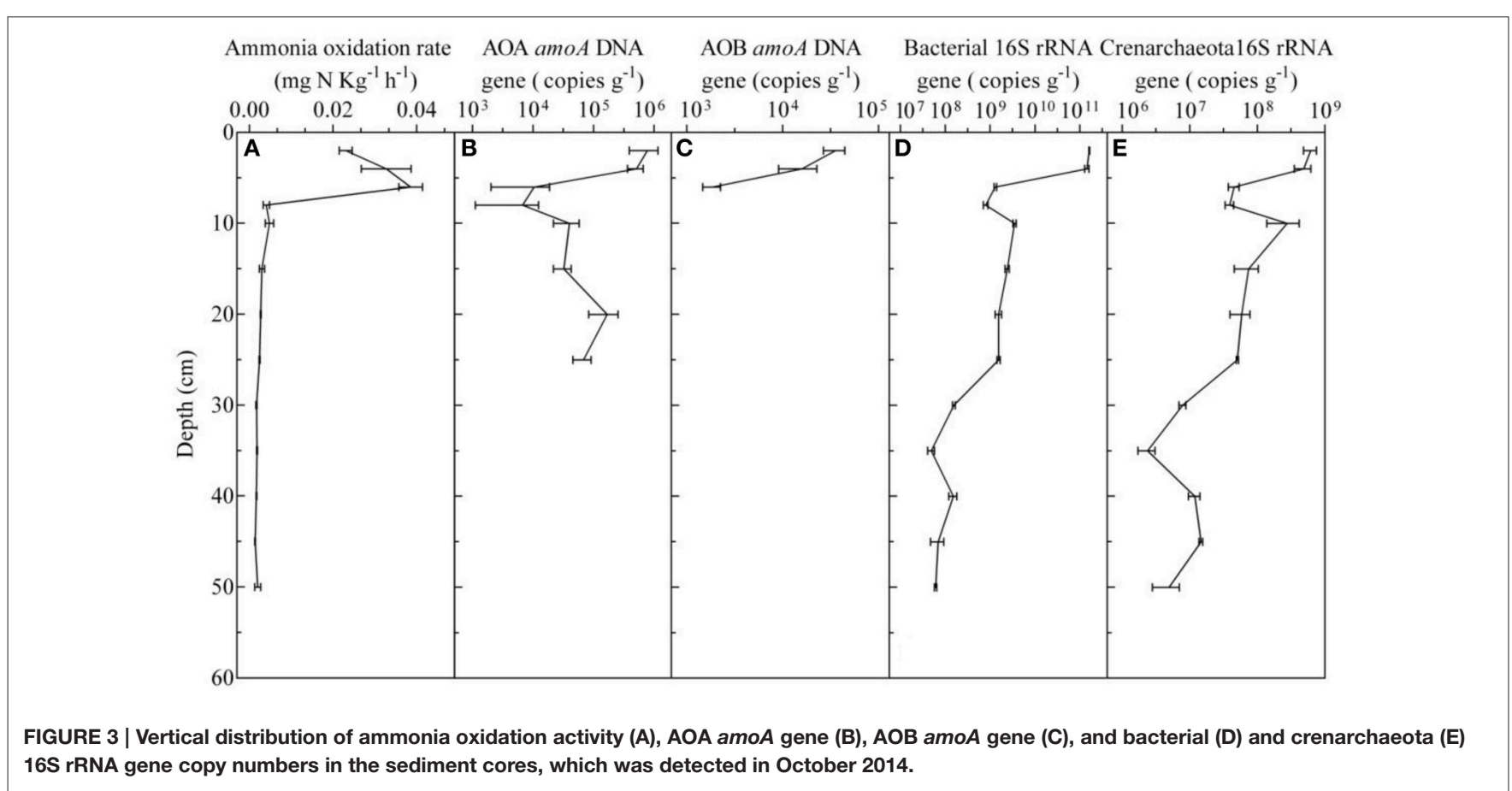




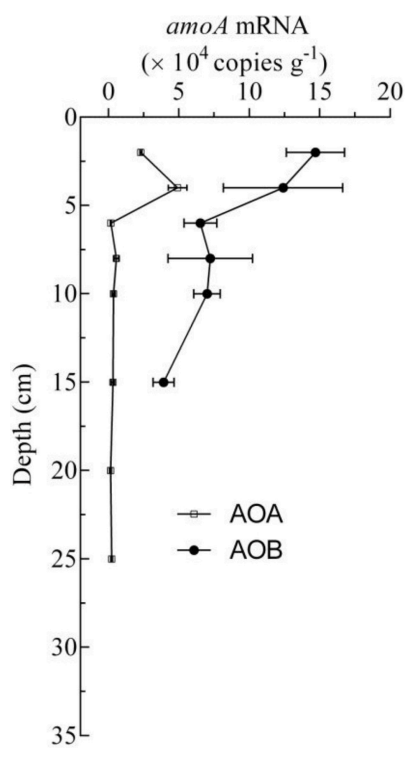

FIGURE 4 | Vertical distribution of transcripts of AOA and AOB amoA mRNA copy numbers in the sediment cores.

\section{DISCUSSION}

\section{Abundances, Ammonia Oxidation Rates, and Expression of $A O A$ and $A O B$}

A significant positive correlation between the abundance of AOA and TOC was observed. This may indicate that AOA are able to assimilate organic substrates and thereby be able to grow mixotrophically or even heterotrophically. This view is supported by studies of archaeal isolates from soil and marine sediments (Tourna et al., 2011; Qin et al., 2014), although our results are quite different from those that showed a negative correlation between AOA abundance and TOC concentrations in the sediments of a eutrophic lake and river (Wu et al., 2010; Wang et al., 2014b).

Because of large depositions of feeding debris and feces in the aquaculture pond, the surface sediments were rich in organic substances and exhibited a high $\mathrm{NH}_{4}^{+}-\mathrm{N}$ concentration (Figure 1). The abundance of the AOA amoA gene was one order of magnitude higher than that of the $\mathrm{AOB}$ in the surface sediment $(0-6 \mathrm{~cm}$ depth), which suggested that AOA, as opposed to $\mathrm{AOB}$, were the numerically predominant ammoniaoxidizing organisms in the surface sediment of the freshwater aquaculture pond. We observed the same phenomenon in 10 other Chinese freshwater pond sediments (Lu et al., 2015). Our result contradicts the concept that AOA prefer lower $\mathrm{NH}_{4}^{+}$concentration environments because of their higher specific affinity for $\mathrm{NH}_{4}^{+}$, whereas $\mathrm{AOB}$ prefer higher $\mathrm{NH}_{4}^{+}$ concentrations (Martens-Habbena et al., 2009; Habteselassie et al., 2013).

$\mathrm{AOA}$, rather than $\mathrm{AOB}$, were the numerically predominant ammonia-oxidizing organisms in the surface sediment. This could be attributed to the fact that $\mathrm{AOA}$ are more resistant to low levels of DO (Coolen et al., 2007; Molina et al., 2010; Bouskill

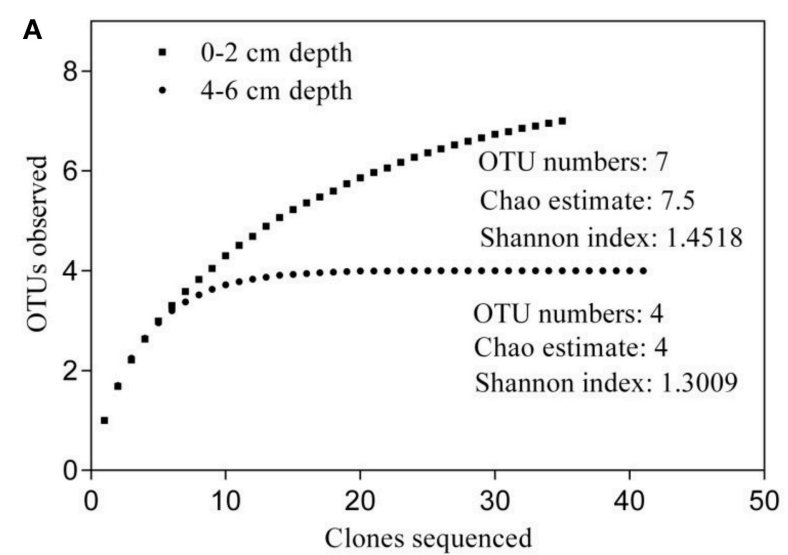

B

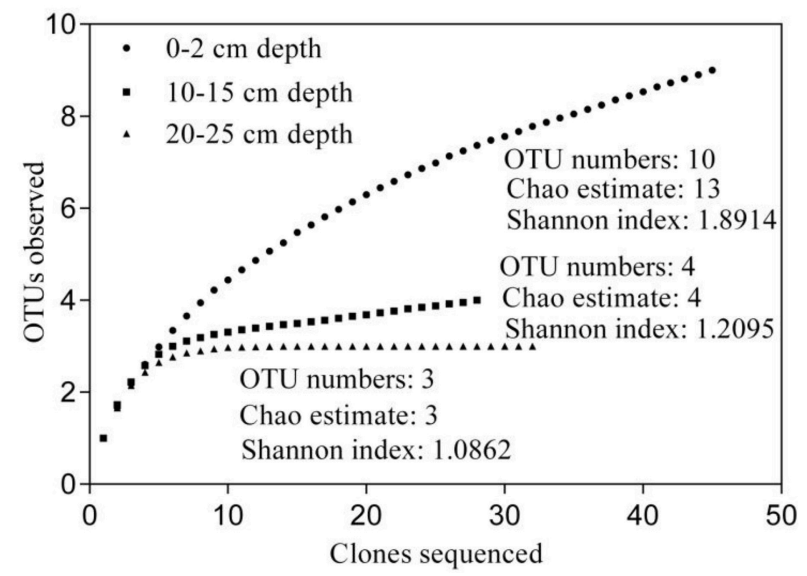

FIGURE 5 | Rarefaction analysis of ammonia-oxidizing bacterial (AOB) (A) and ammonia-oxidizing archaea (AOA) (B) communities in freshwater pond sediment. The DOTUR program was used with $3 \%$ sequence variation for $\mathrm{AOB}$, or with $2 \%$ sequence variation for $\mathrm{AOA}$, for the operation taxonomic unit (OTU) determination.

et al., 2012). The oxygen dynamics in aquaculture ponds differ from those of other aquatic systems, as pond environments are smaller, have limited water circulation, and are subjected to large deposits of feeding debris. The hypolimnion DO concentration was rarely $>62.5 \mu \mathrm{mol} \mathrm{L}^{-1}$ in an aquaculture pond, although the super-saturation of oxygen usually occurs during the daylight period (Chang and Ouyang, 1988). Moreover, for example, the DO concentration at the water-sediment interface was only $48.1 \mu \mathrm{mol} \mathrm{L}^{-1}$ during another season (July 2015), and it reached zero when at depths $>500 \mu \mathrm{m}$.

Apart from the $\mathrm{NH}_{4}^{+}-\mathrm{N}$ and TOC concentrations, $\mathrm{pH}$ has been suggested to be an important environmental factor that influences the distribution of AOB and AOA (He et al., 2007; Yao et al., 2011; Hu et al., 2014; Jiang et al., 2015). In this study, a significant negative correlation was found between $\mathrm{pH}$ and the abundance of the AOA amoA gene, indicating that the number of AOA decreased with decreasing $\mathrm{pH}$-values. This finding is consistent with the physiological features of isolated AOA strains (Jong-Geol et al., 2012; Qin et al., 2014) and previous studies conducted in soil (Nicol et al., 2008; Hu et al., 2014). This effect 


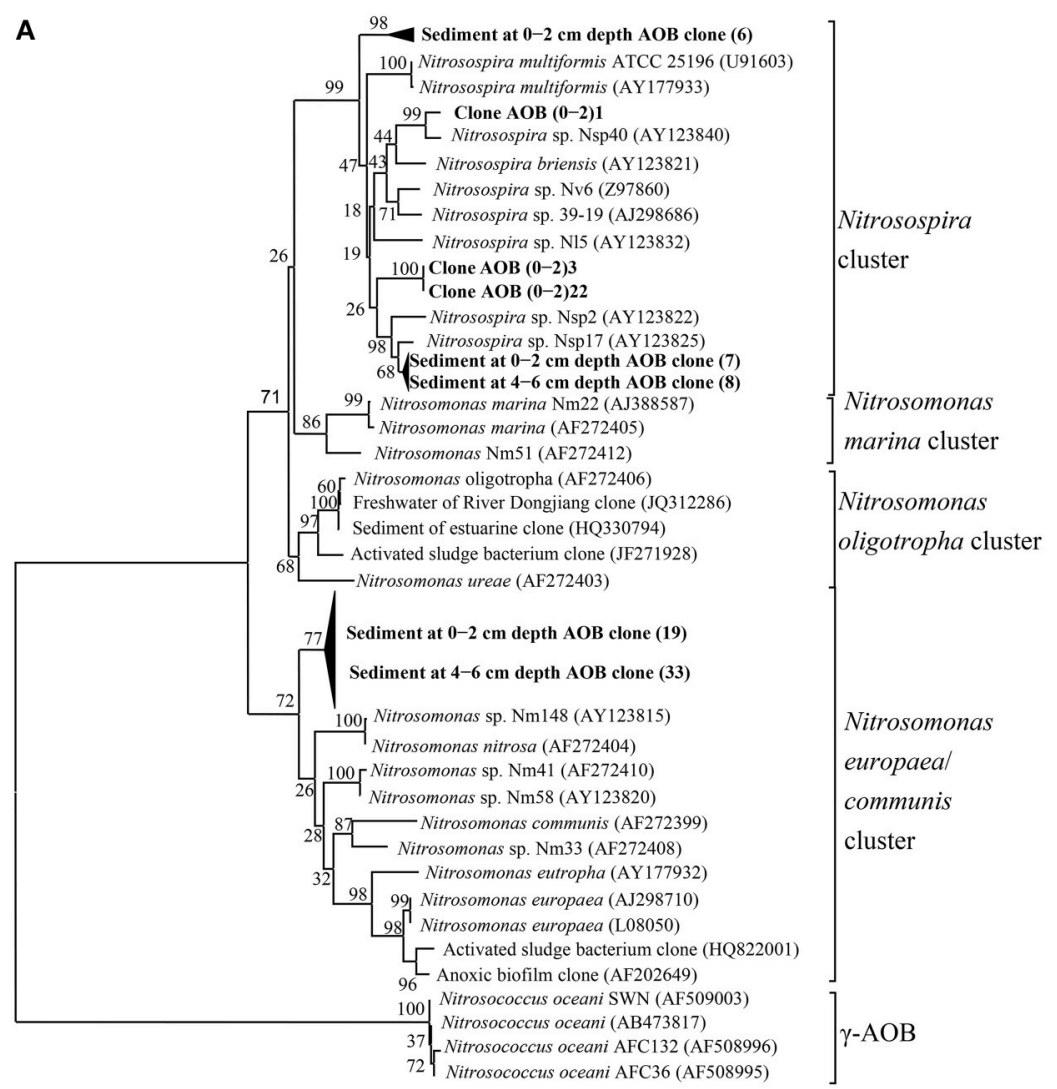

0.1

B

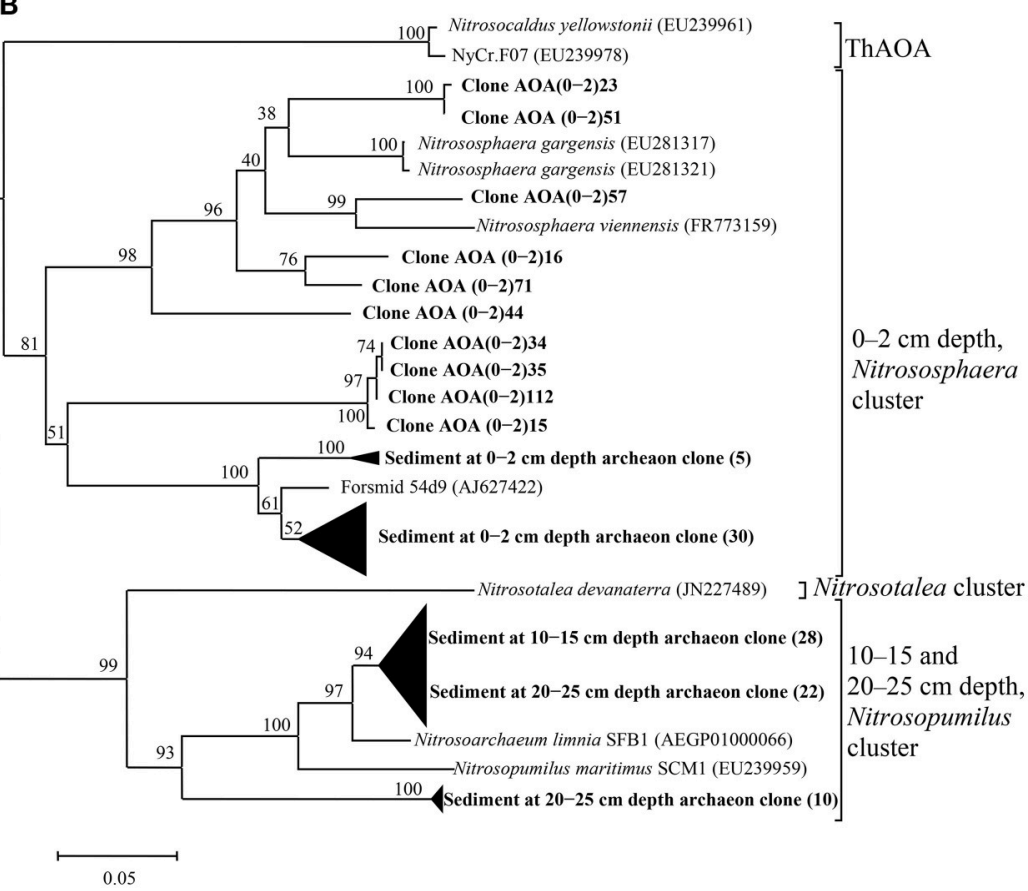

FIGURE 6 | Phylogenetic tree of $A O B$ (A) and AOA (B) based on partial amoA gene sequence (472 bp for AOB and $597 \mathrm{bp}$ for $\mathrm{AOA}$ ) from the aquaculture pond sediment and some related sequences from GenBank reconstructed via the neighbor-joining method by fixing the Kimura 2-parameter evolution model with a bootstrap level of 1000 replications in MEGA 5.0. The numbers close to the nodes represent the bootstrap values 


\section{FIGURE 6 | Continued}

( $n=1000$ replicates); Scale bar represents 0.1 (for AOB) or 0.05 (for AOA) nucleic acid substitutions per nucleotide position; Clones obtained from this experiment are highlighted in bold and are designated by sample names; the numbers in brackets represent the number of clones.

might be associated with the reported requirement for the use of $\mathrm{NH}_{3}$, not $\mathrm{NH}_{4}^{+}$(Martens-Habbena et al., 2009). The sediment $\mathrm{pH}$ was significantly negatively correlated with the abundance of the $\mathrm{AOB}$ amoA gene, indicating that $\mathrm{pH}$ was an important factor that controlled the $\mathrm{AOB}$ abundance in aquaculture pond sediment. This finding is consistent with the result obtained from an alkaline sandy loam (Shen et al., 2008). A study of an AOB isolate from freshwater showed that it could grow in a wide $\mathrm{pH}$ range, although the highest growth rate occurred at $\mathrm{pH} 7-7.5$ (Elizabeth et al., 2012). In this study, the $\mathrm{pH}$ in the surface (0$6 \mathrm{~cm}$ depth) sediment ranged from 7.4 to 7.7. Although the $\mathrm{pH}$ only increased by 0.3 units with depth, the average abundance of AOB decreased 19-fold. The increase in $\mathrm{pH}$ may have decreased AOB growth and abundance.

To better understand the activity of the ammonia-oxidizing community in different sediment layers, potential ammonia oxidation rates were measured in the laboratory. Variations in the potential ammonia oxidation rates were not explained by the concentrations of amoA genes or mRNA in different sediment layers, as the rates did not exhibit any positive correlation with the concentrations of $a m o A$ or mRNA. Perhaps, the potential ammonia oxidation rates should be determined not only by the abundance and expression of $\mathrm{AOB}$ and $\mathrm{AOA}$, but also by the phylotypes of $\mathrm{AOB}$ and $\mathrm{AOA}$, as shown in Figures 6A,B, both of which consisted of different phylotype clusters, which may have different growth and nitrification rates (Bollmann et al., 2002, 2005; Tourna et al., 2011; Jong-Geol et al., 2012).

The results for the expression of amoA mRNA showed that the concentrations of $\mathrm{AOB}$ amoA mRNA was higher than that of AOA by 2.5- to 39.9-fold in the surface sediments $(0-10 \mathrm{~cm}$ depth; Figure 4), although the copy numbers of the AOA amoA gene were higher than those of $\mathrm{AOB}$ by an order of magnitude in the surface sediments $(0-6 \mathrm{~cm}$ depth; Figures $3 \mathrm{~B}, \mathrm{C})$. The results indicated that ammonia oxidation was mainly carried out by AOB in surface sediments $(0-10 \mathrm{~cm}$ depth), and that AOA might be the dominant ammonia-oxidizing microorganisms in deeper sediments ( $>10 \mathrm{~cm}$ depth), where only the AOA amoA gene was detected. A similar phenomenon was found in an agricultural soil, where $\mathrm{AOB}$, rather than $\mathrm{AOA}$, mainly conducted the ammonia oxidation, despite the fact that AOA amoA genes were more numerous than $\mathrm{AOB}$ amoA genes, and which was demonstrated by DNA-stable isotope probing (Jia and Ralf, 2009). In addition, in a temperate forest soil, it was also suggested that $\mathrm{AOB}$ are more involved than $\mathrm{AOA}$ in net nitrification in the top $5 \mathrm{~cm}$ of soil in July, and that AOA amoA genes are more numerous than $\mathrm{AOB} a m o A$ genes in the topsoil (Onodera et al., 2010).

\section{Diversity of AOA and AOB}

The diversity of $\mathrm{AOB}$ has been studied in various ecosystems with molecular tools, and it has been shown that AOB exhibit apparently high biodiversity in many aquatic ecosystems (Nicol et al., 2008; Wu et al., 2010; Jin et al., 2011; Sun et al., 2013). In this study, there were two AOB clusters: the Nitrosospira and Nitrosomonas clusters were found in sediments, and the latter was predominant in both sediment layers (Figure 6A). These results are consistent with previous studies of rhizoplanes of floating aquatic macrophytes, as well rice soils (Nicolaisen et al., 2004; Wang et al., 2009; Wei et al., 2011). Nitrosomonas were often detected in high-nitrogen environments, such as wastewater treatment plants (Geets et al., 2006; Stephanie et al., 2015), and some other studies have suggested that high concentrations of $\mathrm{NH}_{4}^{+}-\mathrm{N}$ could enhance the development of Nitrosomonas spp. relative to Nitrosospira spp. (Bollmann et al., 2002, 2005).

Like AOB, the archaeal $a m o A$ gene was detected in different sediment layers, and all AOA fell within the Nitrososphaera and Nitrosopumilus clusters of the Thaumarchaeota phylum, with the latter being the dominant type (Figure 6B). A similar observation was found in the hyporheic zone of a eutrophic river (Wang et al., 2014b), where two distinct monophyletic clusters were also found, and the diversity of AOA decreased slightly with increasing sediment depth, but the Nitrososphaera cluster was the dominant cluster of archaeal ammonia oxidizers. In addition, the Nitrososphaera cluster represented the majority of AOA in many wastewater treatment plants, where Nitrosopumilus and Nitrososphaera clusters were jointly found (Limpiyakorn et al., 2013). The archaeal sequences were assigned into two branches with a clear difference between the surface and deeper samples, which may be attributed to the higher concentrations of TOC and $\mathrm{NH}_{4}^{+}-\mathrm{N}$ in surface sediment. There was evidence that the Nitrososphaera cluster could bear higher amounts of TOC (Chen et al., 2008; Tourna et al., 2011; Liu et al., 2013) and $\mathrm{NH}_{4}^{+}-\mathrm{N}$ (Tourna et al., 2011) than the Nitrosopumilus cluster. A similar phenomenon was also found in the sediments of the Dongjiang and Qiantang rivers (Liu et al., 2013; Sun et al., 2013). The AOA in deeper pond sediment were all grouped into the Nitrosopumilus cluster, which could be inhibited by organic carbon and prefer relatively lower carbon contents (Könneke et al., 2005).

In summary, our results showed that diversity of AOA and $\mathrm{AOB}$ decreased with increasing sediment depth and different dominant species were found at the different depths sampled. AOA were less active than AOB in surface sediments $(0-10 \mathrm{~cm}$ depth) of the freshwater aquaculture pond, however, where AOA, as opposed to $\mathrm{AOB}$, were the most abundant ammonia-oxidizing organisms. AOA might be the dominant ammonia-oxidizing microorganisms in deeper sediments, where only the AOA amo $A$ gene was detected. This could be attributed to the fact that AOA are more resistant to low levels of DO. These results provide some useful information toward our understanding of freshwater pond sediment and their management, especially for the process of ammonia oxidation in fish pond sediment. 


\section{ACKNOWLEDGMENTS}

This study was financially supported by the National Natural Science Foundation (grant no. 31372570), a project in the National Science \& Technology Pillar Program during the Twelfth Five-year Plan Period (no. 2012BAD25B01), and an

\section{REFERENCES}

Ackefors, H., and Enell, M. (1994). The release of nutrients and organic matter from aquaculture systems in Nordic countries. J. Appl. Ichthyol. 10, 225-241. doi: 10.1111/j.1439-0426.1994.tb00163.x

Amann, R. I., Ludwig, W., and Schleifer, K. H. (1995). Phylogenetic identification and in situ detection of individual microbial cells without cultivation. Microbiol. Rev. 59, 143-169.

Auguet, J. C., Nomokonova, N., Camarero, L., and Casamayor, E. O. (2011). Seasonal changes of freshwater ammonia-oxidizing archaeal assemblages and nitrogen species in oligotrophic alpine lakes. Appl. Environ. Microbiol. 77, 1937-1945. doi: 10.1128/AEM.01213-10

Auguet, J.-C., Triadó-Margarit, X., Nomokonova, N., Camarero, L., and Casamayor, E. O. (2012).Vertical segregation and phylogenetic characterization of ammonia-oxidizing Archaea in a deep oligotrophic lake. ISME J. 6, 1786-1797. doi: 10.1038/ismej.2012.33

Bollmann, A., Bär-Gilissen, M.-J., and Laanbroek, H. J. (2002). Growth at low ammonium concentrations and starvation response as potential factors involved in niche differentiation among ammonia-oxidizing bacteria. Appl. Environ. Microbiol. 68, 4751-4757. doi: 10.1128/AEM.68.10.4751-47 57.2002

Bollmann, A., Schmidt, I., Saunders, A. M., and Nicolaisen, M. H. (2005). Influence of starvation on potential ammonia-oxidizing activity and amoA mRNA levels of Nitrosospira briensis. Appl. Environ. Microbiol. 71, 1276-1282. doi: 10.1128/AEM.71.3.1276-1282.2005

Bouskill, N. J., Eveillard, D., Chien, D., Jayakumar, A., and Ward, B. B. (2012). Environmental factors determining ammonia-oxidizing organism distribution and diversity in marine environments. Environ. Microbiol. 14, 714-729. doi: 10.1111/j.1462-2920.2011.02623.x

Cao, L., Naylor, R., Henriksson, P., Leadbitter, D., Metian, M., Troell, M., et al. (2015). China's aquaculture and the world's wild fisheries. Science 347, 133-135 doi: 10.1126/science.1260149

Chang, W. Y. B., and Ouyang, H. (1988). Dynamics of dissolved oxygen and vertical circulation in fish ponds. Aquaculture 74, 263-276 doi: 10.1016/00448486(88)90370-5

Chen, X., Zhu, Y., Xia, Y., Shen, J., and He, J. (2008). Ammonia-oxidizing archaea: important players in paddy rhizosphere soil? Environ. Microbiol. 8, 1978-1987. doi: 10.1111/j.1462-2920.2008.01613.x

Coolen, M. J. L., Abbas, B., van Bleijswijk, J., Hopmans, E. C., Kuypers, M. M. M., Wakeham, S. G., et al. (2007). Putative ammonia-oxidizing Crenarchaeota in suboxic waters of the black sea: a basin-wide ecological study using $16 \mathrm{~S}$ ribosomal and functional genes and membrane lipids. Environ. Microbiol. 9, 1001-1016. doi: 10.1111/j.1462-2920.2006.01227.x

Elizabeth, F., Jessica, A. K., Maitreyee, M., George, B., and Annette, B. (2012). Ecophysiological characterization of ammonia-oxidizing archaea and bacteria from freshwater. Appl. Environ. Microbiol. 16, 5773-5780. doi: 10.1128/AEM.00432-12

Francis, C. A., Roberts, K. J., Beman, J. M., Santoro, A. E., and Oakley, B. B. (2005). Ubiquity and diversity of ammonia-oxidizing archaea in water columns and sediments of the ocean. Proc. Natl. Acad. Sci. U.S.A. 102, 14683-14688. doi: 10.1073/pnas.0506625102

Geets, J., Boon, N., and Verstraete, W. (2006). Strategies of aerobic ammonia-oxidizing bacteria for coping with nutrient and oxygen fluctuations. FEMS Microbiol. Ecol. 58, 1-13. doi: 10.1111/j.1574-6941.2006. 00170.x

Gundersen, J. K., Ramsing, N. B., and Glud, R. N. (1998). Predicting the signal of $\mathrm{O}_{2}$ microsensors from physical dimensions, temperature, salinity, and $\mathrm{O}_{2}$ concentration. Limnol. Oceanogr. 43, 1932-1937
Open Fund of the Key Laboratory of Fishery Equipment and Engineering, Ministry of Agriculture (grant no. 2014006) of China. We also thank Dr. Liao Ming-jun (College of Resource and Environmental Engineering, Hubei University of Technology, Wuhan 430068, China) for reading the manuscript.

Habteselassie, M. Y., Xu, L., and Norton, J. M. (2013). Ammonia-oxidizer communities in an agricultural soil treated with contrasting nitrogen sources. Front. Microbiol. 4:326. doi: 10.3389/fmicb.2013.00326

He, J.-Z., Shen, J.-P., Zhang, L.-M., Zhu, Y.-G., Zheng, Y.-M., Xu, M.-G., et al. (2007). Quantitative analyses of the abundance and composition of ammoniaoxidizing bacteria and ammonia-oxidizing archaea of a Chinese upland red soil under long-term fertilization practices. Environ. Microbiol. 9, 2364-2374. doi: 10.1111/j.1462-2920.2007.01358.x

Horak, R. E. A., Qin, W., Schauer, A. J., Armbrust, E. V., Ingalls, A. E., Moffett, J. W., et al. (2013). Ammonia oxidation kinetics and temperature sensitivity of a natural marine community dominated by archaea. ISME J. 7, 2023-2033. doi: 10.1038/ismej.2013.75

Hou, L. J., Liu, M., Jiang, H. Y., Xu, S. Y., Ou, D. N., Liu, Q. M., et al. (2003). Ammonium adsorption by tidal flat surface sediments from the Yangtze estuary. Environ. Geol. 45, 72-78. doi: 10.1007/s00254-003-0858-2

Hu, B., Liu, S., Wang, W., Shen, L., Lou, L., Liu, W., et al. (2014). $\mathrm{pH}$-dominated niche segregation of ammonia-oxidising microorganisms in Chinese agricultural soils. FEMS Microbiol. Ecol. 90, 290-299. doi: 10.1111/1574-6941.12391

Jia, Z., and Ralf, C. (2009). Bacteria rather than archaea dominate microbial ammonia oxidation in an agricultural soil. Environ. Microbiol. 11, 1658-1671. doi: 10.1111/j.1462-2920.2009.01891.X

Jiang, X., Hou, X., Zhou, X., Xin, X., Alan, W., and Jia, Z. (2015). pH regulates key players of nitrification in paddy soils. Soil Biol. Biochem. 81, 9-16. doi: 10.1016/j.soilbio.2014.10.025

Jin, T., Zhang, T., Ye, L., Lee, O. O., Wong, Y. H., and Qian, P. Y. (2011). Diversity and quantity of ammonia-oxidizing archaea and bacteria in sediment of the pearl river estuary, china. Appl. Microbiol. Biotechnol. 90, 1137-1145. doi: 10.1007/s00253-011-3107-8

Jong-Geol, K., Man-Young, J., Soo-Je, P., W. I. C. R., Jaap, S. S. D., Eugene, L. M., et al. (2012). Cultivation of a highly enriched ammonia-oxidizing archaeon of thaumarchaeotal group I.1b from an agricultural soil. Environ. Microbiol. 6, 1528-1543. doi: 10.1111/j.1462-2920.2012.02740.x

Könneke, M., Bernhard, A. E., de la Torre, J. R., Walker, C. B., Waterbury, J. B., and Stahl, D. A. (2005). Isolation of an autotrophic ammonia-oxidizing marine archaeon. Nature 437, 543-546. doi: 10.1038/nature03911

Koops, H.-P., and Pommerening-Röser, A. (2001). Distribution and ecophysiology of the nitrifying bacteria emphasizing cultured species. FEMS Microbiol. Ecol. 37, 1-9. doi: 10.1016/s0168-6496(01)00137-4

Kowalchuk, G. A., and Stephen, J. R. (2001). Ammonia-oxidizing bacteria: a model for molecular microbial ecology. Annu. Rev. Microbiol. 55, 485-529 doi: 10.1146/annurev.micro.55.1.485

Kumar, S., Nei, M., Dudley, J., and Tamura, K. (2008). MEGA: a biologistcentric software for evolutionary analysis of DNA and protein sequences. Brief. Bioinform. 9, 299-306. doi: 10.1093/bib/bbn017

Kurola, J., Salkinoja-Salonen, M., Aarnio, T., Hultman, J., and Romantschuk, M. (2005). Activity, diversity and population size of ammonia-oxidizing bacteria in oil-contaminated landfarming soil. FEMS Microbiol. Lett. 250, 33-38. doi: 10.1016/j.femsle.2005.06.057

Leininger, S., Urich, T., Schloter, M., Schwark, L., Qi, J., Nicol, G. W., et al. (2006). Archaea predominate among ammonia-oxidizing prokaryotes in soils. Nature 442, 806-809. doi: 10.1038/nature04983

Limpiyakorn, T., Füerhacker, M., Haberl, R., Chodanon, T., Srithep, P., and Sonthiphand, P. (2013). amoA-encoding archaea in wastewater treatment plants: a review. Appl. Microbiol. Biotechnol. 97, 1425-1439. doi: 10.1007/s00253-012-4650-7

Liu, S., Shen, L., Lou, L., Tian, G., Zheng, P., and Hu, B. (2013). Spatial distribution and factors shaping the niche segregation of ammonia-oxidizing 
microorganisms in the Qiantang River, China. Appl. Environ. Microbiol. 13, 4065-4071. doi: 10.1128/AEM.00543-13

Lu, S., Liao, M., Xie, C., He, X., Li, D., He, L., et al. (2015). Seasonal dynamics of ammonia-oxidizing microoganisms in freshwater aquaculture ponds. Ann. Microbiol.65, 651-657. doi: 10.1007/s13213-014-0903-2

Martens-Habbena, W., Berube, P. M., Urakawa, H., de la Torre, J. R., and Stahl, D. A. (2009). Ammonia oxidation kinetics determine niche separation of nitrifying Archaea and Bacteria. Nature 461, 976-981. doi: 10.1038/nature08465

Merbt, S. N., Stahl, D. A., Casamayor, E. O., Martí, E., Nicol, G. W., and Prosser, J. I. (2012). Differential photoinhibition of bacterial and archaeal ammonia oxidation. FEMS Microbiol. Lett. 327, 41-46. doi: 10.1111/j.15746968.2011.02457.x

Molina, V., Belmar, L., and Ulloa, O. (2010). High diversity of ammoniaoxidizing archaea in permanent and seasonal oxygen-deficient waters of the eastern South Pacific. Environ. Microbiol. 12, 2450-2465. doi: 10.1111/j.14622920.2010.02218.x

Nicol, G. W., Leininger, S., Schleper, C., and Prosser, J. I. (2008). The influence of soil $\mathrm{pH}$ on the diversity, abundance and transcriptional activity of ammonia oxidizing archaea and bacteria. Environ. Microbiol. 10, 2966-2978. doi: 10.1111/j.1462-2920.2008.01701.x

Nicolaisen, M. H., Risgaard-Petersen, N., Revsbech, N. P., Reichardt, W., and Ramsing, N. B. (2004). Nitrification-denitrification dynamics and community structure of ammonia-oxidizing bacteria in a high yield irrigated Philippine rice field. FEMS Microbiol. Ecol. 49, 359-369. doi: 10.1016/j.femsec.2004.04.015

Onodera, Y., Nakagawa, T., Takahashi, R., and Tokuyama, T. (2010). Seasonal change in vertical distribution of ammonia-oxidizing archaea and bacteria and their nitrification in temperate forest soil. Microbes Environ. 25, 28-35. doi: 10.1264/jsme2.ME09179

Pester, M., Rattei, T., Flechl, S., Gröngröft, A., Richter, A., Overmann, J., et al. (2012). amoA-based consensus phylogeny of ammonia-oxidizing archaea and deep sequencing of $a m o A$ genes from soils of four different geographic regions. Environ. Microbiol. 14, 525-539. doi: 10.1111/j.1462-2920.2011.02666.x

Pester, M., Schleper, C., and Wagner, M. (2011). The Thaumarchaeota: an emerging view of their phylogeny and ecophysiology. Curr. Opin. Microbiol. 14, 300-306. doi: 10.1016/j.mib.2011.04.007

Qin, W., Amin, S. A., Martens-Habbena, W., Walker, C. B., Urakawa, H., Devol, A. H., et al. (2014). Marine ammonia-oxidizing archaeal isolates display obligate mixotrophy and wide ecotypic variation. Proc. Natl. Acad. Sci. U.S.A. 111, 12504-12509. doi: 10.1073/pnas.1324115111

Randall, D. J., and Tsui, T. K. N. (2002). Ammonia toxicity in fish. Mar. Pollut. Bull. 45, 17-23 doi: 10.1016/s0025-326x(02)00227-8

Rotthauwe, J. H., Witzel, K. P., and Liesack, W. (1997). The ammonia monooxygenase structural gene $a m o A$ as a functional marker: molecular fine-scale analysis of natural ammonia-oxidizing populations. Appl. Environ. Microbiol. 63, 4704-4712

Schloss, P. D., and Handelsman, J. (2005). Introducing DOTUR, a computer program for defining operational taxonomic units and estimating species richness. Appl. Environ. Microbiol. 71, 1501-1506. doi: 10.1128/AEM.71.3.1501-1506.2005

Shen, J., Zhang, L., Zhu, Y., Zhang, J., and He, J. (2008). Abundance and composition of ammonia-oxidizing bacteria and ammonia-oxidizing archaea communities of an alkaline sandy loam. Environ. Microbiol. 6, 1601-1611. doi: 10.1111/j.1462-2920.2008.01578.x

Stephanie, N. M., Jean-Christophe, A., Alba, B., Eugènia, M., and Emilio, O. C. (2015). Wastewater treatment plant effluents change abundance and composition of ammonia-oxidizing microorganisms in mediterranean urban stream biofilms. Microb. Ecol. 1, 66-74. doi: 10.1007/s00248-014-0464-8

Sun, W., Xia, C., Xu, M., Guo, J., Wang, A., and Sun, G. (2013). Distribution and abundance of archaeal and bacterial ammonia oxidizers in the sediments of the
Dongjiang river, a drinking water supply for Hong Kong. Microbes Environ. 28, 457-465. doi: 10.1264/jsme2.ME13066

Torsten, O., Drazenka, S., Achim, Q., Liza, B.-O., and Christa, S. (2003). Diversity and abundance of Crenarchaeota in terrestrial habitats studied by 16S RNA surveys and real time PCR. Environ. Microbiol. 5, 787-797. doi: 10.1046/j.14622920.2003.00476.x

Tourna, M., Stieglmeier, M., Spang, A., Könneke, M., Schintlmeister, A., Urich, T., et al. (2011). Nitrososphaera viennensis, an ammonia oxidizing archaeon from soil. Proc. Natl. Acad. Sci. U.S.A. 108, 8420-8425. doi: 10.1073/pnas.10134 88108

Wang, X., Wang, C., Bao, L., and Xie, S. (2014a). Abundance and community structure of ammonia-oxidizing microorganisms in reservoir sediment and adjacent soils. Appl. Microbiol. Biotechnol. 98, 1883-1892. doi: 10.1007/s00253013-5174-5

Wang, Y., Ke, X., Wu, L., and Lu, Y. (2009). Community composition of ammonia-oxidizing bacteria and archaea in rice field soil as affected by nitrogen fertilization. Syst. Appl. Microbiol. 32, 27-36. doi: 10.1016/j.syapm.2008.09.007

Wang, Z., Wang, Z., Huang, C., and Pei, Y. (2014b). Vertical distribution of ammonia-oxidizing archaea (AOA) in the hyporheic zone of a eutrophic river in North China. World J. Microbiol. Biotechnol. 30, 1335-1346. doi: 10.1007/s11274-013-1559-y

Wei, B., Yu, X., Zhang, S., and Gu, L. (2011). Comparison of the community structures of ammonia-oxidizing bacteria and archaea in rhizoplanes of floating aquatic macrophytes. Microbiol. Res. 166, 468-474. doi: 10.1016/j.micres.2010.09.001

Wilson, K. H., Blitchington, R. B., and Greene, R. C. (1990). Amplification of bacterial $16 \mathrm{~S}$ ribosomal DNA with polymerase chain reaction. J. Clin. Microbiol. $28,1942-1946$

Wu, Y., Xiang, Y., Wang, J., Zhong, J., He, J., and Wu, Q. L. (2010). Heterogeneity of archaeal and bacterial ammonia-oxidizing communities in Lake Taihu, China. Environ. Microbiol. Rep. 2, 569-576. doi: 10.1111/j.17582229.2010.00146.x

Wuchter, C., Abbas, B., Coolen, M. J., Herfort, L., van Bleijswijl, J., Timmers, P., et al. (2006). Archaeal nitrification in the ocean. Proc. Natl. Acad. Sci. U.S.A. 104, 5704-5704. doi: 10.1073/pnas.0600756103

Yao, H., Gao, Y., Nicol, G. W., Campbell, C. D., Prosser, J. I., Zhang, L., et al. (2011). Links between ammonia oxidizer community structure, abundance, and nitrification potential in acidic soils. Appl. Environ. Microbiol. 77, 4618-4625. doi: 10.1128/AEM.00136-11

Ye, W., Liu, X., Lin, S., Tan, J., Pan, J., Li, D., et al. (2009). The vertical distribution of bacterial and archaeal communities in the water and sediment of Lake Taihu. FEMS Microbiol. Ecol. 70, 263-276. doi: 10.1111/j.1574-6941.2009.00761.x

Zhao, D., Zeng, J., Wan, W., Liang, H., Huang, R., and Wu, Q. L. (2013). Vertical distribution of ammonia-oxidizing archaea and bacteria in sediments of a eutrophic lake. Curr. Microbiol. 67, 327-332. doi: 10.1007/s00284-013-0369-7

Zhu, G., Wang, S., Wang, Y., Wang, C., Risgaard-Petersen, N., Jetten, M. S. M., et al. (2011). Anaerobic ammonia oxidation in a fertilized paddy soil. ISME J. 5, 1905-1912. doi: 10.1038/ismej.2011.63

Conflict of Interest Statement: The authors declare that the research was conducted in the absence of any commercial or financial relationships that could be construed as a potential conflict of interest.

Copyright (C) $2016 \mathrm{Lu}, \mathrm{Liu}, \mathrm{Ma}, \mathrm{Liu}, \mathrm{Wu}$, Zeng, Shi and Gu. This is an open-access article distributed under the terms of the Creative Commons Attribution License (CC $B Y)$. The use, distribution or reproduction in other forums is permitted, provided the original author(s) or licensor are credited and that the original publication in this journal is cited, in accordance with accepted academic practice. No use, distribution or reproduction is permitted which does not comply with these terms. 